Article

\title{
Evaluation of Sustainable Development in Six Transformation Fields of the Central Taiwan Science Park
}

\author{
Fu-Hsuan Chen 1,*D and Hao-Ren Liu ${ }^{2, *}$
}

Citation: Chen, F.-H.; Liu, H.-R. Evaluation of Sustainable Development in Six Transformation Fields of the Central Taiwan Science Park. Sustainability 2021, 13, 4336 https://doi.org/10.3390/su13084336

Academic Editor: Harald Heinrichs

Received: 1 March 2021

Accepted: 1 April 2021

Published: 13 April 2021

Publisher's Note: MDPI stays neutral with regard to jurisdictional claims in published maps and institutional affiliations.

Copyright: (c) 2021 by the authors. Licensee MDPI, Basel, Switzerland. This article is an open access article distributed under the terms and conditions of the Creative Commons Attribution (CC BY) license (https:// creativecommons.org/licenses/by/ $4.0 /)$.
1 Department of Political Science, National Taiwan University, No. 1, Sec. 4, Roosevelt Rd., Taipei 10617, Taiwan

2 Department of Graduate Institute of Building and Planning, National Taiwan University, No. 1, Sec. 4, Roosevelt Rd., Taipei 10617, Taiwan

* Correspondence: fhchen@mail.ntcu.edu.tw (F.-H.C.); d01544007@ntu.edu.tw (H.-R.L.); Tel.: +886-2-3366-3366 (F.-H.C.); Fax: +886-2-2362-7651 (F.-H.C.)

\begin{abstract}
By the establishment of science parks, Taiwan has achieved the ability to form high-tech industrial clusters and provided an environment for sustainable industrial development. This study analyzes the sustainable development strategy of the Central Taiwan Science Park (hereafter CTSP). The questions addressed here include: (1) What is the concept of sustainable development in the CTSP? and (2) How does the research respond to the debate on the significance of the CTSP? The research data have been collected using interviews and observation. According to the literature, eight criteria are identified and set up as a framework to code and analyze the data: "natural resources, accessibility regulatory regime, market demand, development level, proximity condition, parcel conditions, and financial compensation". The framework is then used for evaluating the sustainability of science parks in the light of 17 core goals proposed by the United Nations as Sustainable Development Goals/SDGs for the world. Evaluation of these core goals in the CTSP development revealed the successful transformation of Taiwan's political and economic structure. In this study, the analysis of the sustainable development generated by the science parks indicates Taiwan's transition from state leadership (strong state, weak society) to state guidance (strong state, strong society). However, despite its contribution to the long-term development of Taiwan's economy, the CTSP development has been accompanied by environmental downsides, risking the sustainability goals. In conclusion, the state's role in making CTSP successful and sustainable, the determining role of regulatory regimes, and moving from state leadership to state guidance are emphasized.
\end{abstract}

Keywords: sustainable development; CTSP; science park; SDGs; developmental state theory

\section{Introduction}

The post-war era in Eastern Asia was accompanied by an economic miracle called the developmental state (esp. in Japan, Taiwan, South Korea, Hong Kong, etc.) [1]. Other developing countries (especially Latin America) were added later to the list. The main characteristics of a developmental state include strong state intervention, as well as substantial regulation and planning. Through the establishment of science parks, the Taiwanese government used state power to attract investment and tax subsidies [2]. This has led to achieving a certain degree of success in the regional economy, and has promoted a cluster of technology industries in northern Taiwan [3]. Science park subsidies for industries in Taiwan are used by bureaucrats to lead the "industrial policy", with an oligopolistic and exclusive "market network" controlled by the public sector and large-family businesses [4]. The political business cycle-where power is tilted towards the capital driven by the public sector, "technical innovation" for investment, and platform creation-has become Taiwan's unique economic development model [5].

Taiwan's economic development goal is to actively implement sustainable development goals. It uses science parks as a medium for this purpose. The sustainability concept 
is an approach to meeting the physical, social, economic, and environmental needs of a community without compromising the benefits and needs of future generations [6].

"Sustainable development" was first used by the "International Nature and Natural Resources Conservation Alliance", "United Nations Environment Programme", and "World Wildlife Animal Foundation" three international conservation organizations, published in 1980 proposed in the "World Conservation Program" report [7]. In 1987, the United Nations World Commission on Environment and Development (WCED) published a report called "Our Common Future", where it defines sustainable development as: "It can meet the needs of the present without compromising the satisfaction of future generations" [8]. Taiwan first announced its sustainable development policies in 1994. The "Environmental Basic Law" was passed in 2002. Taiwan's sustainable development policies include "Fairness", "Sustainability" and "Commonality".

In 2015, the United Nations passed a total of 17 Sustainable Development Goals (SDGs) and 169 specific targets, due to the tremendous changes and challenges brought about by emerging global risks [9]. The changes in global sustainable development goals have brought about different results in the Taiwan Science Park. Therefore, the present research investigates the sustainable transformations (successful or unsuccessful) in the Central Taiwan Science Park (CTSP). We will also analyze the sustainable development strategy of the CTSP.

\section{Review of Literature}

\subsection{Developmental State}

The developmental state literature indicates that the success of East Asian development is based on the specific type of country. The current path of the developmental state shows a continuation of economic development plans in East Asian countries from the 1970s to the 2000s [10]. They jointly constructed their development paths with economic administrative institutions, political-business partnerships, and selective industrial policies [11]. The states' position of intervening in industrial economic development is distinctive.

"Developmental state theory" asserted that the focus was on the causal relationship between government intervention and industries or enterprises to produce economic benefits before 2000 [12]. They pointed out that the successful economic development of a country comes from an effective and strong government intervention [13]. Afterward, the core of the development proposal was to promote and improve industrial transformation from the perspective of the institution through the appropriation of technology [14]. They were also to use bureaucratic institutions to embed appropriate intervention policies that maintain the lifeline of the country's industry in Asia, and use the advantages of latecomers to catch up and increase economic productivity efficiency [15].

The conceptual system formed by the evolution of "developmental state" is not only widely used to analyze the process of Taiwan's economic and industrial development in latecomers, but also extends to the discussion of the industrial policy and political regimes [14]. Institutions have promoted manufacturing-led export growth, including the involvement of the World Bank, which was based on low-price workforce and commodities as well as low competition rate; financial systems effectively protected by the government; low-price distortions; dependency on imported technology; as well as a good inclination toward agriculture [16].

The current path of the "developmental state" shows that globalization has changed the role of state transformation into a power interaction network between state and nonstate actors [17]. The relationship between the state and society affects the economic results, making the relationship between the government and the market a governanceinterdependence of public/private cooperation [18]. To survive, developmental countries must respond to changes in the current situation and this encouraged Taiwan to establish a consensus goal for development through democratic deliberations and dialogs. This can be noted in the mode of operation of the CTSP. 


\subsection{Science Parks}

In 1950, a science park was first built in Stanford, California. Later on, in the late 1960s, Cambridge Science Park in England and Sophia Antipolis in France were established. Europe experienced a boom of science parks in the 1980s and 1990s [19]. In studying the cases of developing state or economic take-off regions, notable findings have been achieved in recent years [20]. A science park is usually composed of government, universities, and other higher education institutions, as well as a coalition of private-sector interest groups [21]. In the past, the success of science parks came from the regional development of clusters of science and technology industries. Science parks provided geographical proximity for the upstream, midstream, and downstream manufacturers, professional suppliers, and equipment manufacturers, leading to industry cluster effects in tandem with intermediary institutions [22]. Successful science parks comprise innovative incubation centers and local learning institutions (such as universities, research institutions), etc., which realize collective learning and technology transfer, industrial transformation, and investment in factories [23]. Due to increasing the employment rate in local spaces and the construction of parks, the tax effect of high output value is different from traditional industrial zones [24].

Companies are clustered in the science park and then clustered in industries. The government provides a subsidy, in hopes that the industry can assist with local upgrades and create job opportunities [25]. Regional investment often affects the characteristics of investment in a science park [26]. Some researchers maintain that science parks are not of benefit to local investment. Massey states that science parks are involved with high-tech visions and not all science parks are practical in social, scientific, and space domains [27]. Science parks are now entrenched entities, which are growing in many countries. They are regarded as the frontline of science, extolled as high-status workplaces where novel future innovations are made. Massey et al. [28] believe that science parks are not the main source of technological development since they are not all in agreement with science parks. Bakouros et.al. study of Greek science parks also agrees with Massey that science parks are high-tech speculation. They took Greece as an example and assert that the synergy of science parks was limited and only played a role in commercial and social intercourse [29]. Some science parks have used public budgets despite polluting the environment. Funding has been reallocated to other transnational governments and has not been used to create job opportunities. It has also not benefited the industry in terms of upgrades.

Lee and Yang believe that founding Hsinchu Science Park led to the progress of Taiwan's entire electronic information industry [30]. The influence of different science parks on the local, regional, or national economy varies greatly [31]. The impact depends on the motivation behind the innovation driving the establishment of the science park. Castells and Hall listed three main motivations for establishing technology parks and science parks [32]:

1. Reindustrialization,

2. Regional development,

3. Creating synergy.

Science parks will create technological growth poles, mainly due to the Internet technology revolution, globalization, and the emergence of new economic production and management forms [33]. Hsinchu (Taiwan), Sophia Antipolis (France), and Cambridge (UK), are the three "technology parks" dominated by high-tech companies, where their developmental state institutions and universities participate in technological development as well [34].

The science park is a policy tool to promote research-oriented industries and activities, which aims to build innovative high-tech industries and related products in concentrated areas, as well as make greater contributions to the emerging economies [35]. The scale of science parks has a direct relationship with the growth of per capita income in the city where science parks are located [36]. During economic downturns, the benefits provided by science parks will increase the outcomes at regional and firm levels. Although there 
are many studies on science parks, there are no conclusive studies. However, at the same time, research on these effects has come to conflicting conclusions, and often points out a relative absence of interaction between science park organizations [37]. The universal literature on the definite functionality of science parks is not consistent [38]. This study uses the science park as a case of sustainable development of public management. The overall goal of the site selection for the newly established parks is for "Taiwan's economy and regional development" to strengthens the regional innovation integration momentum and elevate the innovation of domestic high-tech industries.

\subsection{Taiwan Science Park Characteristics}

Taiwan science parks have several strong points in public administration, which contribute to their sustainability.

1. The science park bureau simplifies and integrates the service flow in administration, one-stop fast service, business authorization of each department, and service efficiency improvement [39].

2. A science-based enterprise, officially approved for establishment in the park, is involved in innovation, manufacturing, and research and development (R\&D) of hightech products or services [40].

3. Emphasis on research and development as well as innovation to improve industrial competitiveness [41].

4. High-quality investment environment, attracting high-tech flagship factories [42].

5. Construct complete upstream, midstream, and downstream industrial clusters and spread regional clustering effects [43].

6. The land is only rented but not sold, reducing the cost for manufacturers to build factories [44].

7. Establishing bilingual experimental schools, attracting high-tech talents at home and abroad [45].

\subsection{Taiwan's SDGs and the Political Regime}

In response to the UN Earth Summit of 1992, the National Council for Sustainable Development (NCSD) was established in August 1997. The NCSD, which is convened by the premier, consists of seven working groups and two task forces. NCSD has completed several important documents on Taiwan's sustainable development, including Taiwan's Agenda 21, the Taiwan Sustainable Development Indicator System, National Sustainable Development Policy Guidelines, Taiwan's Declaration on Sustainable Development and the Sustainable Development Action Plans. These documents are working guidelines for the government and the public to promote sustainable development and review the related progress [46].

In this regard, the United Nations has proposed 17 core goals as Sustainable Development Goals (SDGs) to be pursued and promoted by governments (see Figure 1). Aimed at sustainable development, in 2017 and 2018, Taiwan held the second-stage citizen forum. Through this public policy network participation platform, with 2020 as the time point, Taiwan's specific SDG goals and corresponding guidelines were proposed. According to the six transformation actions proposed by TWI2050, Taiwan's sustainable development goals have been revised repeatedly [47]. In the end, various ministries will integrate international trends, domestic needs, expert suggestions, and citizen opinions, and confirm and put forward 18 core goals, 143 specific goals, and corresponding indicators [48]. These mainly include climate change, population aging, infectious diseases, energy stability and security, wealth gap, economic growth and employment, etc. [49]. In 2018, "Transformations to Achieve the SDGs" pointed out that the key in implementing sustainable development goals lies in the following six transformation actions [50]. In 2018, the first report by TWI2050 on "Transformations to Achieve the Sustainable Development Goals" identified six exemplary transformations required to achieve the SDGs and long-term sustainability by 2050 and beyond: (i) Human capacity, demography, and health; (ii) Consumption and 
production; (iii) Decarbonization and energy, (iv) Food, biosphere, and water; (v) Smart cities; and (vi) Digital revolution. The overarching strategy is to strengthen the five key aspects of the transition to sustainable development, i.e., systems, society, nature, human resources, and manufacturing.

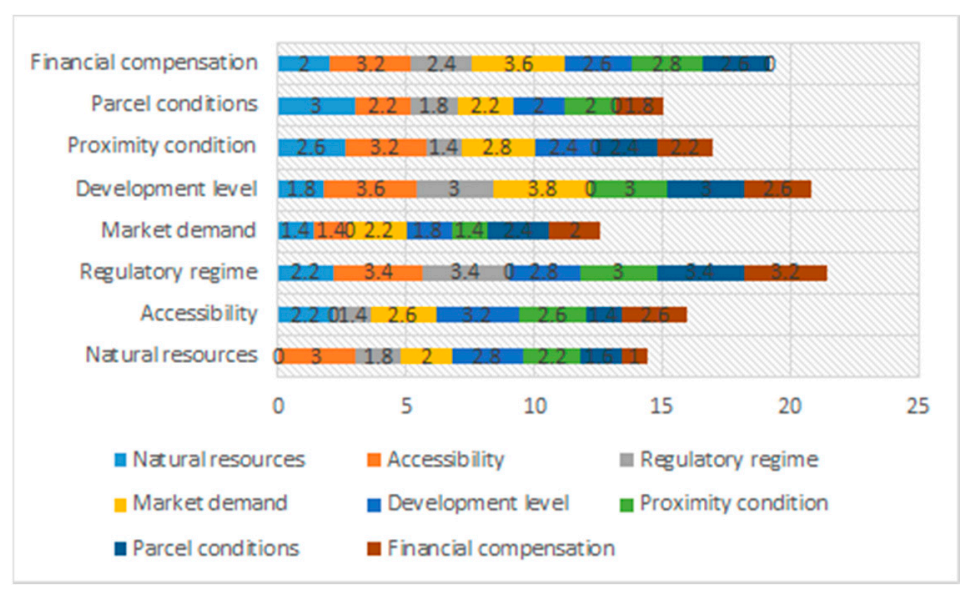

Figure 1. Matrix causality comparison scale.

Taiwan science parks in general, and the CTSP in particular, have been an integral part of the sustainability policies of the government. Therefore, in the present study, the 17 core goals proposed by the United Nations Sustainable Development Goals (SDGs) are analyzed and discussed to evaluate the sustainable development and transformation achieved by the science parks [51].

\section{Materials and Methods}

According to the Taiwan government's "Act for Establishment and Administration of Science Parks" [38], science parks should be established with careful consideration of environmental conditions, development potential, and development execution. In a way that agrees with the research literature, there are 8 major indicators of an established science park, namely, natural resources [52], accessibility [53], regulatory regime [54], market demand [55], development level [56], proximity condition [57], parcel conditions [58], and financial compensation [59]. These indicators were used to set up a framework to evaluate CTSP sustainability development. The indicators were scored by the experts who participated in the interviews. The author sought the committee's (the 37 interviewees) consensus on the relative weights of each, and used Matrix Causality Comparison Scale to determine the most important factor.

This research took the quality research of the science park as a niche, and it was carried out in three stages:

In the first stage, a short survey was conducted with neighboring individuals to determine their feelings on having a Taiwan Science Park in their neighborhood. The other participants were interviewed thereafter.

In the second stage, data were collected and a survey analysis was run to determine the common denominator between opinions and questions regarding the Taiwan Science Park.

The third stage was conducted to run a comparative analysis of the cause-and-effect matrix, analyze the conflicting issues, identify the key issues during the survey analysis, and list the general negative effects. Thereafter, a root cause conflict analysis diagram was drafted and functional analysis was performed. Once this was completed, the way forward regarding the transformation of the Taiwan Science Park was determined.

The interview subjects were originally 37 individuals who were divided into four groups: scholars and experts, CTSP industry owners, government officials, and residents near the science park (the nearby villages' heads represented the locals). The survey included 5 open-end questions evaluating these criteria: the infrastructure of the area, 
the environmental changes due to the development of science parks, the sustainability or insufficiency of government policies, the training of professional and technical personnel, and the role of the government in CTSP investment incentives measures. After the interview ended, the sequence was re-coded. The detailed interview statistics are listed in the following section.

\section{Data Collection}

Data collection methods include in-depth interviews, e-mail surveys, and telephone interviews with stakeholders such as employees, neighboring communities, civil service agencies, non-governmental organizations, academic research institutions, and all business services.

The questionnaires were marked as A, B, C, and D for each group of respondents. The interviews are conducted on five major topic areas using open-ended questions.

\section{Data Analysis}

For the result scores of the indicators, a pairwise comparison is run, using evaluation scales 0 to 4 , as shown in Table 1 :

0 refers to No impact

1 refers to Minimal impact

2 refers to Low impact

3 refers to Moderate impact

4 refers to a relation with critical influence

Table 1. List of interviewees in the survey.

\begin{tabular}{|c|c|c|c|}
\hline Interviewee & Interviewee's Job/Expertise Category & Original Code & Number of Interviewees \\
\hline \multirow{3}{*}{$\begin{array}{c}\text { Academic Research Institution } \\
\text { Scholar Expert/A }\end{array}$} & Political economy/A1 & A1-1 A1-3 & 3 \\
\hline & Industrial Economy/A2 & A2-1 A2-2 & 2 \\
\hline & $\begin{array}{c}\text { Industrial Park Development/Regional } \\
\text { Development Policy/A3 }\end{array}$ & A3-1 A3-3 & 3 \\
\hline \multirow{4}{*}{ CTSP industry owners/B } & Optoelectronics/B1 & B1-1 & 1 \\
\hline & Precision machinery/B2 & B2-1 B2-4 & 4 \\
\hline & Biotechnology/B3 & B3-1 B3-2 & 2 \\
\hline & Central government officials/C1 & $\mathrm{C} 1-1 \sim \mathrm{C} 1-10$ & 10 \\
\hline Government officials/C & $\begin{array}{c}\text { Elected chief and deputy heads of local } \\
\text { governments / } 22\end{array}$ & $\mathrm{C} 2-1 \sim \mathrm{C} 2-2$ & 2 \\
\hline $\begin{array}{l}\text { Residents in neighboring } \\
\text { communities of } 10 \mathrm{~km} / \mathrm{D}\end{array}$ & $\begin{array}{c}\text { Heads of the surrounding } 10 \\
\text { km-community and science park } \\
\text { village/D1 }\end{array}$ & D1-1 D1-10 & 10 \\
\hline
\end{tabular}

According to the literature, eight criteria are identified and set up as a framework to code and analyze the data: "natural resources, accessibility regulatory regime, market demand, development level, proximity condition, parcel conditions, and financial compensation". The direct impact relation matrix representing the influence is normalized as D, which is obtained through the normalization of the mean matrix. All main diagonal indexes are equal to 0 . After comparing all the causal relationships, the total score is obtained. The highest total score is the most intuitive reason. The matrix grading table derived from the interview questionnaire shows that the regulatory regime is the most important factor affecting the science parks in Taiwan, as shown in the following Figure 1:

With the added column summation and row summation of the total influence relationship matrix, it was found that the regulatory regime has the largest weight. Using the compiled data, the problems in a regulatory regime are listed in the following table. The negative reasons provided by the interviewees indicate both the surface and potential reasons. 
In Table 2, the interview questions are analyzed to find the source of conflict in the opinion of the interviewees. Thereafter, the key conflict points are drawn. This table also reveals the scope of the transformation and governance of the CTSP, during the political and economic changes from 2004 to 2019.

Table 2. The analysis of current situation survey forms.

\begin{tabular}{|c|c|c|c|}
\hline & Questions & Conflict Key Point & Match 8 Criteria \\
\hline 1 & $\begin{array}{l}\text { Do you agree/or not that } \\
\text { science parks will affect } \\
\text { sustainability and change the } \\
\text { appearance of local settlements? }\end{array}$ & $\begin{array}{l}\text { The CTSP has set up many parks and they } \\
\text { are scattered around Central Taiwan, and } \\
\text { the infrastructure, such as roads and } \\
\text { factories, change the appearance of the } \\
\text { local settlement. }\end{array}$ & $\begin{array}{l}\text { Natural resources, accessibility } \\
\text { regulatory regime, market demand, } \\
\text { development level, proximity condition, } \\
\text { parcel conditions, and } \\
\text { financial compensation. }\end{array}$ \\
\hline 2 & $\begin{array}{l}\text { Are local residents worried } \\
\text { about the environment being } \\
\text { changed and are they fighting } \\
\text { against the development of the } \\
\text { science park? }\end{array}$ & $\begin{array}{l}\text { The efficiency of the science and } \\
\text { technology bureaucracy activates attracting } \\
\text { investment. Although this is an attraction, } \\
\text { the environment is being affected. Local } \\
\text { residents will fight against the } \\
\text { establishment of science parks. }\end{array}$ & $\begin{array}{l}\text { Natural resources, accessibility } \\
\text { regulatory regime, market demand, } \\
\text { development level, proximity condition, } \\
\text { parcel conditions, and } \\
\text { financial compensation. }\end{array}$ \\
\hline 3 & $\begin{array}{l}\text { Is the policy sustainable } \\
\text { or insufficient? }\end{array}$ & $\begin{array}{l}\text { Policies tend to be short-term populism } \\
\text { during pre-elections, and there is a lack of } \\
\text { consensus to pursue a sustainable } \\
\text { overall development. }\end{array}$ & $\begin{array}{l}\text { Natural resources, accessibility } \\
\text { regulatory regime, market demand, } \\
\text { development level, proximity condition, } \\
\text { parcel conditions, and } \\
\text { financial compensation. }\end{array}$ \\
\hline 4 & $\begin{array}{l}\text { Is there sufficient training of } \\
\text { professional and } \\
\text { technical personnel? }\end{array}$ & $\begin{array}{l}\text { The surrounding universities cannot } \\
\text { provide skillful technical staff, and the } \\
\text { company still needs to train this kind of } \\
\text { staff for a long period of time. }\end{array}$ & $\begin{array}{l}\text { Natural resources, accessibility } \\
\text { regulatory regime, market demand, } \\
\text { development level, proximity condition, } \\
\text { parcel conditions, and } \\
\text { financial compensation. }\end{array}$ \\
\hline 5 & $\begin{array}{l}\text { Is there an entry } \\
\text { application system? }\end{array}$ & $\begin{array}{l}\text { The conditions for investment promotion } \\
\text { are too strict, limited to high-tech } \\
\text { manufacturers. The entry procedures are } \\
\text { cumbersome and the time frame is } \\
\text { too long. }\end{array}$ & $\begin{array}{c}\text { Accessibility regulatory regime, market } \\
\text { demand, development level, proximity } \\
\text { condition, parcel conditions, and } \\
\text { financial compensation. }\end{array}$ \\
\hline
\end{tabular}

\section{Results and Discussion}

As shown in Figure 2, the CTSP has six major transformation fields, including "Strengthening the capacity of human resources" (goals 1, 3, 4, 5), "Circular economy" (goals 8, 12), "Energy transformation and acceleration of decarbonization" (goals 7, 13), "Sustainable food and farming system and ecological conservation" (goals 6, 15), "Smart cities" (goals 9, 11), and "Sustainability-oriented digital revolution" (goals 4, 8, 10). The matching of transformation fields with the respective SDG goal is based on the TWI2050 (2018) document published by the government. Moreover, an item of "Cross-domain integration" was established for Goal 16 and Goal 17, i.e., creating a partnership to achieve Taiwan's economic goals through strong institutions, which cross the seven major transformation fields in CTSP.

National leaders have a consensus on pursuing national economic development and actively pursue this goal, a vital characteristic for the survival of a developmental state [60]. However, according to our findings, local residents are bearing many problems caused by this development; such as the transformation of the rural landscape, traffic jams, pollution, and relocations. This, besides the increasing environmental awareness of local citizens, has led to a decrease in "the perceived sense of national development mission" of political elites and technocrats. The key point of this conflict lies in bureaucratic autonomy and the "synchronized development and simultaneous investment policy" under administrative guidance. The positive effect is "promotion" and "economic development", 
while the negative effect is "doubts about environmental pollution", which result in a lack of integration with localities. The impact of science-based enterprises in the park on environmental quality is inseparable from its long-term contribution to economic growth and employment rate.

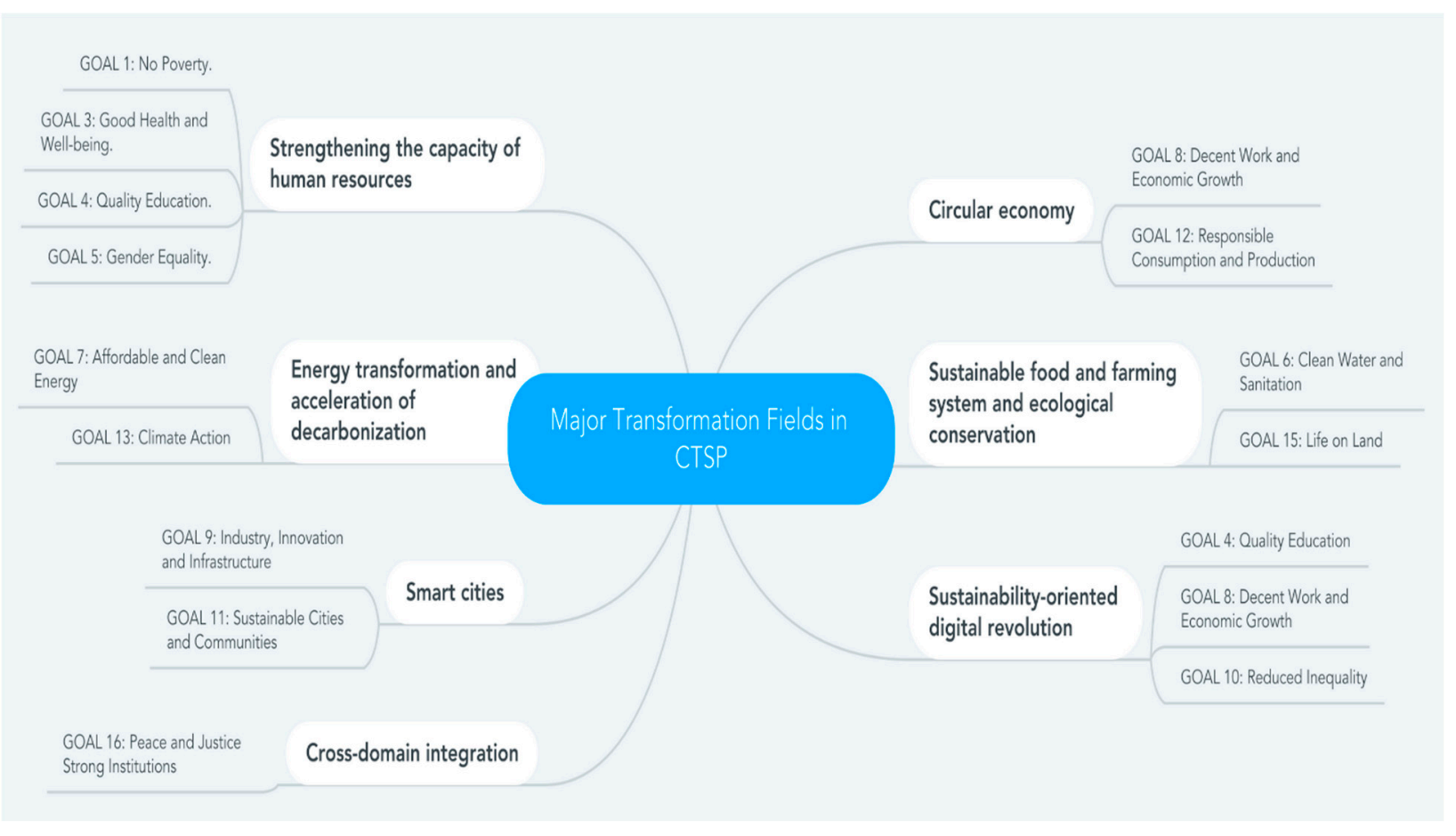

Figure 2. Major Transformation Fields in the Central Taiwan Science Park (CTSP).

\subsection{The CTSP Sustainable Performance}

Since their inception in the 1980s, developmental states entered their prime in the 1990s and 2000s [61]. So far, there have been attempts to determine the democratization and the success of the transformation of Taiwan's political and economic structure, by studying the development history of the CTSP, investigating its flaws and strong points. Transformation of the economy, environment, and society is strong in the CTSP. In the following, the CTSP performance is evaluated in the areas of economy, environment, and society based on sustainable development [62].

The CTSP performance in the economy is increasing from 2004 to 2020:

1. Strengthening the capacity of human resources: Co-organized into 32 sessions of recruitment events.

2. Sustainability-oriented digital revolution: Introduced a total of 206 manufacturers.

3. Sustainability-oriented digital revolution: The turnover reached NTD 797.232 billion, an increase of 9.98\% in a year (2019) compared with 2018.

4. Strengthening the capacity of human resources: The number of employees reached 50,817.

5. Smart cities: Organized 11 sessions of investment briefings at home and abroad.

The CTSP has achieved a good environmental performance, including energy consumption, recycling, and reuse, up to $94 \%$ :

1. Sustainable food and farming system and ecological conservation: Provided 972 cases of consulting services concerning environmental protection.

2. Energy transformation and acceleration of decarbonization: Provided guidance to 5 manufacturers, and the energy efficiency potential amounted to 33,823 thousand kWh of electricity every year, reducing approximately 18,028 tons of CO2e emission. It reduces approximately 18,028 tons of CO2e emissions. 
3. Circular economy: Provided guidance to 3 manufacturers, and the total water conservation potential amounted to 374,855 tons/year.

4. Energy transformation and acceleration of decarbonization: Provided guidance to 3 manufacturers, reducing 59.98 tons of $\mathrm{CO} 2 \mathrm{e} /$ annual emission potential.

5. Energy transformation and acceleration of decarbonization: By providing guidance to the manufacturers in the park for water and electricity conservation, 18,087 tons of CO2e emissions could be saved.

1. Circular economy: The average reuse rate of waste in the parks has reached $93.6 \%$.

2. Sustainable food and farming system and ecological conservation: Carried out 2131 items of environmental monitoring projects.

3. Sustainable food and farming system and ecological conservation: A total of 15 species of protected birds were found in the ecological survey.

4. Sustainable food and farming system and ecological conservation: Conducted a total of 17 sessions of environmental protection tracking, supervision meetings, and on-site inspections.

5. Energy transformation and acceleration of decarbonization: By taking the free shuttle bus, it reduced approximately 137 tons of $\mathrm{CO} 2 \mathrm{e}$ emission.

6. Smart cities: A total of 137,864 people took the free shuttle bus.

7. Cross-domain integration: Organized environmental education courses, with a total of 2765 participants.

CTSP has achieved high satisfaction among the interest groups in terms of social performance:

1. Cross-domain integration: The overall satisfaction score in 2019 was 88.97 points.

2. Sustainability-oriented digital revolution: The CTSP provided counseling to 60 teams selected in the "From IP to IPO Program (FITI)" and fruitful results were achieved.

3. Strengthening the capacity of human resources: For the labor supervision and inspection program, 15 project inspection programs and 650 sessions of labor supervision and inspection were implemented.

4. Strengthening the capacity of human resources: Organized a neighborly healthcare plan in Houli Park to provide health check-ups for residents meeting health check conditions. A total of 232 sessions of public awareness were held.

5. Strengthening the capacity of human resources: 4917 people received telephone interviews in a neighborhood health care plan in Houli Park.

6. Strengthening the capacity of human resources: 3406 people received health examinations in the neighborhood health care plan in Houli Park.

7. Strengthening the capacity of human resources: Conducted epidemiology tracking (once every 5 years), and the cumulative number of people receiving questionnaire surveys and blood biochemical tests reached 1453 people.

8. Strengthening the capacity of human resources: A total of 7427 talents with master's or doctoral degrees needed in the industries received the cultivation program.

9. Strengthening the capacity of human resources: 23 teams in the "From IP to IPO Program (FITI)" set up new start-ups through the project.

The analysis of the sustainable development of science parks in this study, indicates Taiwan's transition from state leadership (strong state, weak society) to state guidance (strong state, strong society) (see Table 3).

Table 3. The strengths of the state and society [63].

\begin{tabular}{ccc}
\hline & Strong State & Weak State \\
\hline Strong Society & state-induced & society-led \\
Weak Society & state-led & Anarchy \\
\hline
\end{tabular}




\subsection{How Does the Research Respond to the Debate on the Significance of the CTSP?}

\subsubsection{Landscape Location and Spatial Distribution}

According to the information released by the Taiwan government at the end of 2020, the CTSP has currently five satellite parks including Taichung Park, Houli Park, Huwei Park, Erlin Park, and Nantou Park. Their connectivities are significantly growing and could have an impact on sustainability.

\subsubsection{CTSP Role in Public Administration}

The key factor in the rapid development of the CTSP was the land acquisition method. The provision of land by the state was sustainability management in public administration, the early development of the CTSP could be synchronized with mass manufacturing production. This was a manifestation of public leadership. An interviewee in Group C stated that Dadu Mountain in Taichung was originally a sweet potato and sugarcane field, and the surrounding living circle was later established by the CTSP. The science park administration had many authorities including investment promotion, 24-h customs clearance, environmental safety, labor administration, construction management registration, fire protection and construction civil engineering, etc. Therefore, the interviewee described the role and authority played by the Science Park Administration as a "small executive Yuan" in multilevel public administration.

\subsubsection{CTSP Sustainable Transformation}

As mentioned above, 6 major fields have transformed in the CTSP: "Strengthening the capacity of human resources", "Circular economy", "Energy transformation and acceleration of decarbonization", "Sustainable food and farming system and ecological conservation", "Smart cities", and "Sustainability-oriented digital revolution." The CTSP serves the regional living circle with the innovative energy of the park, and this supports the innovative development of the park. It is mainly divided into the following modes:

1. Innovative technology driver

It strengthens regional cooperation, shapes local development vision, and jointly builds an open innovation system; and

Leading regional innovation development strategy planning takes place in the CTSP, assisting in the development of park technology and product commercialization. This is driven under the co-innovation development strategy planning, according to specific development issues, integrating various technologies, needs, research, policies, and other resources.

\section{Resource leverage}

It guides local diversified industries to participate and provide innovative experimental field environments; and

Derives emerging industries, products, and service solutions, and becomes an organism of continuous innovation; and uses the entire city as a living laboratory for emerging technology applications (Living Labs). Chinese cities are also developing not only traditional industry but also innovative ones [64].

\section{Network Serialize}

The CTSP pays more attention to the wisdom and talents of the people, encourages them to participate in innovation, and implements a people-oriented innovation model [65].

It also extends the scope of the park to form a complete and rich block of living functions, and provides an open space for interactive communication. From the perspective of people, the innovation area creates various hardware and software facilities that meet the basic human needs of infrastructure and services. The science park is built with the idea of an environment suitable for human settlements, promoting the establishment of a community. The option of education for scholars within the science park is available to the public. 
The presence of manufacturers breaks the barriers of office space and creates a new space design, shortens the distance between employees. It establishes a relationship of mutual trust and mutual sharing, and successfully integrates work into life, thereby improving the ability of employees to innovate and their economic power in the world is growing [62].

\section{Local Industry Promoters}

In the course of transformation of science parks, the definition of development is no longer based on economic industrialization and employment rate, and more attention is paid to environmental and ecological issues. In the process of democratizing local governance, decentralization has become a trend in advanced democracies. Whether additional local participation will help increase the state of public trust or will cause the weakening of state power is yet to be determined. The new-generation park operation model should be able to combine the local characteristics of industries to activate the regional economy and act as an innovation drive [66].

\section{Conclusions}

The present paper is a case study of sustainable development in the CTSP, which tries to prove the successful transformation of Taiwan's political and economic structure by analyzing the 17 core goals of SDGs. The evaluation of sustainability in the CTSP revealed the spill-over effect of this institution, emphasizing its importance in Taiwan's economic development. As stated by interview results, there are new challenges to overcome sustainability hindrances, such as awareness of the negative environmental impacts of the CTSP, therefore, the following conclusions on the sustainable development of science parks in developmental states are drawn:

The figure obtained through the survey shows that the regulatory regime is the most important factor influencing the science parks. There is no support from the state and therefore the development of the science park is not running smoothly.

Democratization has reduced national autonomy. However, from the analysis of the CTSP case, people's requirements and demands for environmental and transparency issues are gradually increasing. Taking the developmental state model in the CTSP as an example, it was found that public administration has an influential effect on sustainable development.

Its export value and employment population were released in 2019; the science park is still in the growth stage of development, but CTSP has leaped out of the "global network economy", "spatial repair of global capital", and the other science parks. The main reason for the discussion of the "regional relevance of corporate geographic expansion" lies in the fact that local forces influence the development of the park. It is not a capitalist market type, but a state-oriented model with a strong state and society.

For the science parks, the success of the development is not plainly defined as economic growth, but in allowing human development to be sustainable. On the one hand, the technical bureaucracy and organizational capabilities of the science park are still the foundation for its success. On the other hand, the local chiefs fought for the establishment of science parks for elections to improve local infrastructure and make the science parks a form of institutionalizing cluster governance in Taiwan. However, since 2008, the CTSP has been facing the difficulties of recent development struggles. Based on the development history of the CTSP and interview data, this study believes that the structure of Taiwan's developmental state is still there, not as a factor of capitalist development, but the government's role has changed from leading the state to inducing it. On the contrary, they have adapted and developed, and still assume the social mission role of "market guidance", far beyond the scope of neoliberalism.

It is concluded that although the state still maintains the structure of economic development in the CTSP, it will gradually give priority to social and environmental factors. Therefore, recently science parks have been given sustainable environmental governance to bring a positive impact on people's lives. From the analysis of the root causes of conflicts, it can be concluded that state economic development is restricted by social pressure, in response to which the industrial development strategy adopted by the science park is to 
gradually adjust to "combine production, innovation, $R \& D$, and cross-border exchanges, and other multi-functional science parks to drive regional economic development". The government uses sustainability in new science parks as the core value of a policy that seeks relatively stable economic development.

As a recommendation for further research, the author suggests that interested scholars study the scope of the CTSP impact on the environment, since environmental concerns were one of the main findings of this study. In addition to production and research activities, the author recommends that the manufacturers continue to strengthen university cooperation. Since 2013, the Government has launched programs (FITI for instance) in science parks and universities to provide resources and promote entrepreneurial fields, besides services such as counseling and training, providing facilities for successful practitioners to be invited to the park and improve its professionalism.

Author Contributions: Writing—original draft, F.-H.C.; Writing—review \& editing, F.-H.C. and H.-R.L. All authors have read and agreed to the published version of the manuscript.

Funding: This research received no external funding.

Institutional Review Board Statement: Not applicable.

Informed Consent Statement: Informed consent was obtained from all subjects involved in the study.

Data Availability Statement: Not applicable.

Conflicts of Interest: The authors declare no conflict of interest.

\section{References}

1. Stubbs, R. What ever happened to the East Asian Developmental State? The unfolding debate. Pac. Rev. 2009, 22, 1-22. [CrossRef]

2. Wade, R.H. The Developmental State: Dead or Alive? Dev. Chang. 2018, 49, 518-546. [CrossRef]

3. Chen, C.-J.; Wu, H.-L.; Lin, B.-W. Evaluating the development of high-tech industries: Taiwan's science park. Technol. Forecast. Soc. Chang. 2006, 73, 452-465. [CrossRef]

4. Zhu, H.; Chung, C.-N. Portfolios of Political Ties and Business Group Strategy in Emerging Economies. Adm. Sci. Q. 2014, 59, 599-638. [CrossRef]

5. Chen, C.-P.; Chien, C.-F.; Lai, C.-T. Cluster policies and industry development in the Hsinchu Science Park: A retrospective review after 30 years. Innovation 2013, 15, 416-436. [CrossRef]

6. Giddings, B.; Hopwood, B.; O'Brien, G. Environment, economy and society: Fitting them together into sustainable development. Sustain. Dev. 2002, 10, 187-196. [CrossRef]

7. Brown, B.J.; Hanson, M.E.; Liverman, D.M.; Merideth, R.W., Jr. Global sustainability: Toward definition. Environ. Manag. 1987, 11, 713-719. [CrossRef]

8. Keeble, B.R. The Brundtland report: 'Our common future'. Med. War 1988, 4, 17-25. [CrossRef]

9. Sachs, J.D. From Millennium Development Goals to Sustainable Development Goals. Lancet 2012, 379, 2206-2211. [CrossRef]

10. Chang, H.-J.; Woo-Cumings, M. How to 'Do' a Developmental State. Constructing a Democratic Developmental State in South Africa; HSRC: Pretoria, South Africa, 2010; p. 88.

11. Chemouni, B.; Dye, B. The Contradictions of an Aspiring Developmental State: Energy Boom and Bureaucratic Independence in Rwanda. SSRN Electron. J. 2020. [CrossRef]

12. Johnson, C. 4. Political Institutions and Economic Performance: The Government-Business Relationship in Japan, South Korea, and Taiwau. In The Political Economy of the New Asian Industrialism; Cornell University Press: Ithaca, NY, USA, 2019; pp. 136-164.

13. Haggard, S. Institutions and growth in East Asia. Stud. Comp. Int. Dev. 2004, 38, 53-81. [CrossRef]

14. Woo-Cumings, M. The Developmental State; Cornell University Press: Ithaca, NY, USA, 2019. [CrossRef]

15. Chu, W.-W. Can Taiwan's second movers upgrade via branding? Res. Policy 2009, 38, 1054-1065. [CrossRef]

16. Department, W.B.P.R.; Birdsall, N.; Page, J. East Asian Miracle: Economic Growth and Public Policy; World Bank, Policy Research Department: Washington, DC, USA, 1993.

17. Weiss, L. Governed interdependence: Rethinking the government-business relationship in East Asia. Pac. Rev. 1995, 8, 589-616. [CrossRef]

18. Weiss, L.; Hobson, J.M. States and Economic Development: A Comparative Historical Analysis; Polity Press Cambridge: Cambridge, UK, 1995.

19. Hobbs, K.G.; Link, A.N.; Scott, J.T. Science and technology parks: An annotated and analytical literature review. J. Technol. Transf. 2017, 42, 957-976. [CrossRef]

20. Hansson, F.; Husted, K.; Vestergaard, J. Second generation science parks: From structural holes jockeys to social capital catalysts of the knowledge society. Technovation 2005, 25, 1039-1049. [CrossRef] 
21. Löfsten, H.; Lindelöf, P. Science Parks and the Growth of New Technology-Based Firms-Academic-Industry Links, Innova-tion and Markets. Res. Policy 2002, 31, 859-876. [CrossRef]

22. Gerschenkron, A. Economic Backwardness in Historical Perspective-The Political Economy Reader: Markets as Institutions; Routledge: London, UK, 1962; pp. 211-228.

23. Amsden, A.H. Asias Next Giant-How Korea Competes in the World-Economy. Technol. Rev. 1989, 92, 46-53.

24. Castells, M. Technopoles of the World: The Making of 21st Century Industrial Complexes; Routledge: London, UK, 2014.

25. Saxenian, A.; Hsu, J.-Y. The Silicon Valley-Hsinchu Connection: Technical Communities and Industrial Upgrading. Ind. Corp. Change 2001, 10, 893-920. [CrossRef]

26. Lecluyse, L.; Knockaert, M.; Spithoven, A. The contribution of science parks: A literature review and future research agenda. J. Technol. Transf. 2018, 44, 559-595. [CrossRef]

27. Kenney, M.; Massey, D.; Quintas, P.; Wield, D. High Tech Fantasies: Science Parks in Society, Science and Space. Contemp. Sociol. A J. Rev. 1993, 22, 428. [CrossRef]

28. Massey, D.; Wield, D. Science Parks: A Concept in Science, Society, and 'Space' (A Realist Tale). Environ Plan D 1992, 10, 411-422. [CrossRef]

29. Bakouros, Y.L.; Mardas, D.C.; Varsakelis, N.C. Science park, a high-tech fantasy? An analysis of the science parks of Greece. Technovation 2002, 22, 123-128. [CrossRef]

30. Lee, W.-H.; Yang, W.-T. The cradle of Taiwan high technology industry development-Hsinchu Science Park (HSP). Technovation 2000, 20, 55-59. [CrossRef]

31. Dabrowska, J.; de Faria, A.F. Performance Measures to Assess the Success of Contemporary Science Parks. Triple Helix 2020, 1, 1-43. [CrossRef]

32. Hall, M.J.; Layson, S.K.; Link, A.N. The returns to R\&D: Division of Policy Research and Analysis at the National Science Foundation. Sci. Public Policy 2013, 41, 458-463. [CrossRef]

33. Koh, F.C.; Koh, W.T.; Tschang, F.T. An analytical framework for science parks and technology districts with an application to Singapore. J. Bus. Ventur. 2005, 20, 217-239. [CrossRef]

34. Díez-Vial, I.; Fernández-Olmos, M. The effect of science and technology parks on firms' performance: How can firms benefit most under economic downturns? Technol. Anal. Strat. Manag. 2017, 29, 1153-1166. [CrossRef]

35. Albahari, A.; Pérez-Canto, S.; Barge-Gil, A.; Modrego, A. Technology Parks versus Science Parks: Does the university make the difference? Technol. Forecast. Soc. Chang. 2017, 116, 13-28. [CrossRef]

36. Annerstedt, J. Science Parks and High-Tech Clustering. In International Handbook on Industrial Policy; Edward Elgar Publishing: Northampton, UK, 2006.

37. Salmador, M.P.; Hansson, F. Science Parks as Knowledge Organizations-the "Ba" in Action? Eur. J. Innov. Manag. 2007, 10, 348-366.

38. Poonjan, A.; Tanner, A.N. The role of regional contextual factors for science and technology parks: A conceptual framework. Eur. Plan. Stud. 2019, 28, 400-420. [CrossRef]

39. Heinrichs, H.; Laws, N. "Sustainability State" in the Making? Institutionalization of Sustainability in German Federal Policy Making. Sustainability 2014, 6, 2623-2641. [CrossRef]

40. Yan, M.-R.; Chien, K.-M.; Hong, L.-Y.; Yang, T.-N. Evaluating the Collaborative Ecosystem for an Innovation-Driven Economy: A Systems Analysis and Case Study of Science Parks. Sustainability 2018, 10, 887. [CrossRef]

41. Dodgson, M.; Mathews, J.; Kastelle, T.; Hu, M.-C. The evolving nature of Taiwan's national innovation system: The case of biotechnology innovation networks. Res. Policy 2008, 37, 430-445. [CrossRef]

42. Ibitz, A. Assessing Taiwan's endeavors towards a circular economy: The electronics sector. Asia Eur. J. 2020, 18, 493-510. [CrossRef]

43. Chan, K.F.; Lau, T. Assessing Technology Incubator Programs in the Science Park: The Good, the Bad and the Ugly. Technovation 2005, 25, 1215-1228. [CrossRef]

44. So, B.W.Y. Reassessment of the state role in the development of high-tech industry: A case study of Taiwan's Hsinchu Science Park. East Asia 2006, 23, 61-86. [CrossRef]

45. Saxenian, A. The Silicon Valley-Hsinchu Connection: Technical Communities and Industrial Upgrading. Berkeley Plan. J. 2012, 15. [CrossRef]

46. Kung, S.-F.; Yen, Y.-C. A sustainable planning approach for science parks: The case of the Southern Taiwan Science Park. Sustain. Dev. Plan. IV 2009, 120, 141-150. [CrossRef]

47. Sachs, J.D.; Schmidt-Traub, G.; Mazzucato, M.; Messner, D.; Nakicenovic, N.; Rockström, J. Six Transformations to Achieve the Sustainable Development Goals. Nat. Sustain. 2019, 2, 805-814. [CrossRef]

48. UN Department of Economic and Social Affairs. Sustainable Development Goals Report 2018; UN Department of Economic and Social Affairs: New York, NY, USA, 2018.

49. Hopwood, B.; Mellor, M.; O’Brien, G. Sustainable development: Mapping different approaches. Sustain. Dev. 2005, 13, 38-52. [CrossRef]

50. TWI2050 Report: Transformations to Achieve the Sustainable Development Goals—Report 2018-IIASA. Available online: https:/ /iiasa.ac.at/web/home/research/twi/Report2018.html (accessed on 28 March 2021). 
51. United Nations General Assembly. Transforming Our World: The 2030 Agenda for Sustainable Development; United Nations General Assembly: New York, NY, USA, 2015.

52. Lin, C.-L.; Tzeng, G.-H. A value-created system of science (technology) park by using DEMATEL. Expert Syst. Appl. 2009, 36, 9683-9697. [CrossRef]

53. Páez, A.; Scott, D.M.; Morency, C. Measuring accessibility: Positive and normative implementations of various accessibility indicators. J. Transp. Geogr. 2012, 25, 141-153. [CrossRef]

54. Chen, J.K.; Sun, B.S.; Batchuluun, A. Exploring the influence factors for creation one Knowledge hub of Science Park: Comparison between Silicon Valley and Hsinchu Science Park. In Proceedings of the 2016 Portland International Conference on Management of Engineering and Technology (PICMET), Honolulu, HI, USA, 4-8 September 2016; pp. 1156-1171.

55. Yang, C.-H.; Motohashi, K.; Chen, J.-R. Are new technology-based firms located on science parks really more innovative? Res. Policy 2009, 38, 77-85. [CrossRef]

56. Chen, H.-S.; Chien, L.-H.; Hsieh, T. A study of assessment indicators for environmental sustainable development of science parks in Taiwan. Environ. Monit. Assess. 2013, 185, 7001-7012. [CrossRef] [PubMed]

57. Jongwanich, J.; Kohpaiboon, A.; Yang, C.-H. Science park, triple helix, and regional innovative capacity: Province-level evidence from China. J. Asia Pac. Econ. 2013, 19, 333-352. [CrossRef]

58. Albahari, A.; Catalano, G.; Landoni, P. Evaluation of national science park systems: A theoretical framework and its application to the Italian and Spanish systems. Technol. Anal. Strat. Manag. 2013, 25, 599-614. [CrossRef]

59. Chen, H.-S. Using Water Footprints for Examining the Sustainable Development of Science Parks. Sustainability 2015, 7, 5521-5541. [CrossRef]

60. Lauridsen, L.S. Governance and Economic Transformation in Taiwan: The Role of Politics. Dev. Policy Rev. 2014, 32, 427-448. [CrossRef]

61. Haggard, S. Developmental States; Cambridge University Press: Cambridge, UK, 2018.

62. Central Taiwan Science Park Administration Site Area of Corporate Social Responsibility. Available online: http://www.ctspcsr. com.tw/eng/ (accessed on 10 January 2021).

63. Deyo, F.C. Beneath the Miracle: Labor Subordination in the New Asian Industrialism; University of California Press: Berkeley, CA, USA, 1989.

64. Raźniak, P.; Dorocki, S.; Winiarczyk-Raźniak, A. Spatial changes in the command and control function of cities based on the corporate centre of gravity model. Misc. Geogr. 2020, 24, 35-41. [CrossRef]

65. Derudder, B.; Cao, Z.; Liu, X.; Shen, W.; Dai, L.; Zhang, W.; Caset, F.; Witlox, F.; Taylor, P.J. Changing Connectivities of Chinese Cities in the World City Network, 2010-2016. Chin. Geogr. Sci. 2018, 28, 183-201. [CrossRef]

66. Dorocki, S.; Raźniak, P.; Winiarczyk-Raźniak, A.; Boguś, M. The Role of Global Cities in Creation of Innovative Industry Sectors Case Study-Life Sciences Sector. In Proceedings of the 5th International Conference IMES, Prague, Czech Republic, 25-26 May 2017; Dvouletý, O., Lukeš, M., Mísar, J., Eds.; pp. 136-146. [CrossRef] 